\title{
BONE MINERAL DENSITY, VITAMIN D AND ANTICONVULSANT THERAPY
}

\author{
SILVANA FILARDI*, CARLOS A.M. GUERREIRO**, \\ LUIS ALBERTO MAGNA***, JOÃO FRANCISCO MARQUES NETO*
}

\begin{abstract}
The aim of this study was to assess bone mineral density and vitamin D metabolism in patients on chronic anticonvulsant therapy. Methods: Sixty-nine men, outpatients on chronic anticonvulsant therapy, who had been treated for at least 5 years, were studied, comparing them to thirty healthy controls. Bone mineral density was measured as well as serum levels of calcium, ionized calcium, alkaline phosphatase, PTH, 25-hydroxycholecalciferol and 1,25-dihydroxycholecalciferol. Results: No differences in bone mineral density, serum levels of vitamin D and intact-PTH were observed between patients and controls. Bone mineral density was not associated with chronic anticonvulsant therapy. Conclusion: Those adult patients who were on chronic anticonvulsant therapy and who lived in low latitude regions had normal bone mineral density as well as vitamin D serum levels.
\end{abstract}

KEY WORDS: vitamin D, calcium, anticonvulsant, bone mineral density.

\section{Densidade mineral óssea, vitamina D e terapia anticonvulsivante}

RESUMO - O objetivo deste estudo foi avaliar a densidade mineral óssea e o metabolismo da vitamina $\mathrm{D}$ em usuários crônicos de anticonvulsivantes. Métodos: Foram estudados 69 pacientes ambulatoriais, masculinos, usuários crônicos de anticonvulsivantes por período mínimo de 5 anos e comparados a 30 controles normais. Foram efetuadas as medidas da densidade mineral óssea e dos níveis plasmáticos do cálcio, cálcio iônico, fosfatase alcalina, paratormônio, 25-hidroxi-colecalciferol e 1,25-di-hidroxi-colecalciferol. Resultados: Nenhuma diferença na densidade mineral óssea e nos níveis plasmáticos da vitamina $\mathrm{D}$ e paratormônio foram observadas entre os pacientes e os controles. A densidade mineral óssea não se mostrou associada ao uso crônico de anticonvulsivantes. Conclusões: Pacientes adultos, do sexo masculino, usuários crônicos de anticonvulsivantes, residentes em regiões ensolaradas, têm densidade mineral óssea e níveis plasmáticos de vitamina D normais.

PALAVRAS-CHAVE: vitamina D, cálcio, anticonvulsivante, densidade mineral óssea.

Alterations in calcium, vitamin D and bone tissue metabolism have been associated with the following drugs: phenobarbital, phenytoin, primidone and carbamazepine ${ }^{1,2}$. Alterations in the metabolism of calcium are generally very slight and subclinical, but clear cases of hypocalcemia could occur in $4 \%$ to $30 \%$ of individuals. The intensity of the clinical symptoms depends on many factors, such as: intake of vitamin D, exposure to the sun, physical activity, other diseases that interfere in vitamin D metabolism, the positive correlation of these manifestations with the type of drug, individual drug dosage, and period of exposure, as well as polytherapy ${ }^{3,6}$.

This study, which was conducted to assess bone mineral density and vitamin D metabolism in a sample of the Brazilian epileptic population on chronic anticonvulsant therapy, was motivated by the fact that the intensity of alterations of vitamin D metabolism and bone mass was related not only to the chronic use of anticonvulsants but also to other variables. These included the characteristics of the population, such as sunlight exposure.

Faculdade de Ciências Médicas (FCM) da Universidade Estadual de Campinas (UNICAMP). *Disciplina de Reumatologia; **Departmento de Neurologia; ***Departmento de Genética Médica. Aceite: 28-abril-2000.

Dr. Carlos A.M. Guerreiro - Departamento de Neurologia FCM-UNICAMP - Caixa Postal 6111 13083-970 Campinas SP - Brasil. 


\section{METHOD}

Sixty-nine epileptic men, outpatients at the Sector for Epilepsy, Department of Neurology, UNICAMP, were retrospectively evaluated.

The mean age of these patients was 37.6 years $(\mathrm{SD}=10.92)$, all being on single or combined anticonvulsant therapy consisting of phenobarbital, phenytoin and carbamazepine for at least a period of 5 years (Table 1 and Table 2). The patients were kept on single or combined anticonvulsant therapy with the same drug for an average period of 10.33 years $(\mathrm{SD}=5.54)$.

The control group consisted of 30 healthy men and the mean age was 34.6 years $(\mathrm{SD}=9.26)$. The exclusion criterion used was: antecedents or the presence of diseases that could cause alterations in the metabolism of calcium and vitamin D. All the participants were from a 20 to 24 degree south latitude region and had similar mean weight and height.

The serum levels of calcium, ionized calcium, alkaline phosphatase, albumin, PTH, 25hydroxycholecalciferol and 1,25 dihydroxycholecalciferol were measured. Radioimmunoassay was used to measure the intact-PTH molecule (NIKOLS, USA) and it was also used to measure 25-hydroxy-vitamin D and 1,25-dihydroxy-vitamin D (interassay coefficient of variation was 14.96 and 18.93 respectively and intra-assay coefficient of variation was 11.08 and 12.13 respectively - INCSTAR (USA).

LUNAR - DEXA equipment with double emission X-rays (DPX) was used to measure bone mineral density (BMD) in the lumbar region of the spine and in the femoral neck $(\mathrm{CV}=2 \%)$.

For the comparison of independent variables, Student $t$ test or Mann-Whitney U test was used, where appropriate. Multiple regression analysis was carried out to verify the relationship between bone mineral density and the use of anticonvulsant therapy, duration of the therapy, body mass index, age, serum levels of calcium, ionized calcium, alkaline phosphatase and albumin. Statistical analysis was done by SAS statistic package. For the comparison of bone mineral density between the different anticonvulsants drug treatments, Kruskal-Wallis and Student $t$ tests were used. For all statistical tests, significance was defined as $p<0.05$.

Table 1. Patients according to the therapy used.

\begin{tabular}{lcc}
\hline Therapeutic scheme & Number & Percentage \% \\
\hline Carbamazepine & 35 & 50 \\
Phenytoin & 12 & 17 \\
Phenobarbital & 11 & 16 \\
Phenobarbital+Carbamazepine & 5 & 7 \\
Phenytoin+Carbamazepine & 2 & 3 \\
Phenobarbital+Phenytoin & 3 & 5 \\
Phenobarbital+Phenytoin+Carbamazepine & 1 & 2 \\
\hline
\end{tabular}

Table 2. Patients according to the anticonvulsant therapy and the dosage used in single or combined therapy for at least 5 years.

Dose (mg/dia)

\begin{tabular}{lccc} 
Anticonvulsant & Number & Mean & SD \\
\hline Phenobarbital & 17 & 123.33 & 56.27 \\
Phenytoin & 16 & 334.37 & 110.63 \\
Carbamazepine & 39 & 1072.0 & 388.48 \\
\hline
\end{tabular}


Table 3. Bone mineral density results of the patients in comparison with the control group.

\begin{tabular}{llcccc}
\hline \multicolumn{7}{c}{ Bone mineral density $\left(\mathrm{g} / \mathrm{cm}^{2}\right)$} \\
\hline \multicolumn{7}{c}{ patient $(\mathrm{n}=69)$} & \multicolumn{2}{c}{ control $(\mathrm{n}=28)$} \\
& mean & SD & mean & SD & p \\
Spine (L2-L4) & 1.181 & 0.127 & 1.215 & 0.147 & 0.252 \\
Femoral neck & 1.043 & 0.122 & 1.052 & 0.178 & 0.782 \\
\hline
\end{tabular}

\section{RESULTS}

Anticonvulsant chronic users did not show a reduction in BMD (Table 3).

The mean serum levels of vitamin D and PTH, observed in the patients, were the same as those of the control group. The mean serum calcium levels were lower and the mean serum phosphatase alkaline and albumin levels were higher in the anticonvulsant users than in the controls (Table 4).

Bone mineral density was not influenced by anticonvulsant therapy, period of treatment, body mass index, serum levels of calcium, alkaline phosphatase, albumin and ionized calcium (Table5).

Table 4. Comparing laboratory exams.

\begin{tabular}{lccccccc}
\hline Variable & \multicolumn{5}{c}{ Patients } & \multicolumn{3}{c}{ Control } \\
& $\mathrm{n}$ & mean & $\mathrm{SD}$ & $\mathrm{n}$ & mean & SD & $\mathrm{p}^{*}$ \\
\hline PTH $(\mathrm{pg} / \mathrm{ml})$ & 27 & 22.796 & 12.949 & 15 & 25.133 & 11.073 & 0.869 \\
25(OH)VITD (ng/ml) & 29 & 32.010 & 10.336 & 25 & 33.160 & 10.501 & 0.211 \\
$1,25(\mathrm{OH}) 2 \mathrm{VITD}(\mathrm{pg} / \mathrm{ml})$ & 28 & 27.271 & 10.264 & 23 & 24.192 & 8.787 & 0.462 \\
Calcium (mg/dl) & 68 & 8.978 & 0.466 & 30 & 9.263 & 0.503 & $0.008^{*}$ \\
Alkaline phosphatase (UI) & 59 & 216.156 & 69.14 & 30 & 171.833 & 42.764 & $0.001^{*}$ \\
Albumin (g/dl) & 64 & 4.173 & 0.440 & 30 & 3.838 & 0.371 & $0.0002^{*}$ \\
\hline
\end{tabular}

$* \mathrm{p}<0.05$

Table 5. Evaluation of the relationship between bone mineral density and the use of anticonvulsant therapy, body mass index, age, duration of the therapy, calcium, ionized calcium, alkaline phosphatase and albumin.

\begin{tabular}{|c|c|c|c|c|}
\hline \multirow[t]{2}{*}{ Variable } & \multicolumn{2}{|c|}{$\begin{array}{l}\text { Bone mineral density } \\
\text { (Spine) }\end{array}$} & \multicolumn{2}{|c|}{$\begin{array}{l}\text { Bone mineral density } \\
\text { (Femoral neck) }\end{array}$} \\
\hline & Parameter estimate & $\mathrm{p}$ & Parameter estimate & $\mathrm{p}$ \\
\hline Intercep & 1.195 & 0.013 & 1.337 & 0.002 \\
\hline Anticonvulsant therapy & -0.034 & 0.407 & -0.046 & 0.753 \\
\hline Body mass index & -0.001 & 0.843 & 0.007 & 0.089 \\
\hline Age & -0.002 & 0.407 & -0.006 & 0.016 \\
\hline Duration of the therapy & 0.000 & 0.883 & 0.001 & 0.753 \\
\hline Calcium & 0.018 & 0.617 & -0.012 & 0.714 \\
\hline Alkaline Phosphatase & 0.000 & 0.914 & -0.000 & 0.768 \\
\hline Albumin & 0.012 & 0.802 & -0.007 & 0.870 \\
\hline Ionized calcium & -0.076 & 0.761 & -0.098 & 0.662 \\
\hline R2 & \multicolumn{2}{|c|}{0.062} & \multicolumn{2}{|c|}{0.181} \\
\hline
\end{tabular}


Bone mineral density in spine and femoral neck was not influenced by the kind of anticonvulsant used ( $\mathrm{p}=0.729$ and $\mathrm{p}=0.824$, respectively) or by single or combined-drug therapy $(\mathrm{p}=0.240$ and $\mathrm{p}=0.653$, respectively).

\section{DISCUSSION}

Bone mineral density was not decreased and vitamin D serum levels were normal in the population studied. There are some risk factors that induce alterations in vitamin D metabolism and bone disease in chronic anticonvulsant users.

These patients were at low risk for these abnormalities because of the following reasons: First, the population in this study consisted of outpatients that had routine physical outdoor activity. Second, as long as the exposure to sunlight is adequate, the most important source of vitamin D is endogenous ${ }^{3}$. The skin synthesis of vitamin $\mathrm{D}$ depends on the intensity of sunlight and the quantity of ultra-violet rays that reach the earth and these are inversely related to latitude ${ }^{7}$. The production of vitamin $\mathrm{D}$, by the skin, varies according to the season in regions that have greater latitude and production is less during autumn/winter. In these regions, exogenous sources of vitamin D are very important to maintain the daily vitamin needs of the normal population ${ }^{8}$ and especially in the case of anticonvulsant users, where the necessity for this vitamin is greater, because the hepatic enzyme system activity increases the catabolism of this vitamin into inactive products ${ }^{1,5}$. Phenobarbital, phenytoin, primidone and carbamazepine increase the hepatic microsomal enzyme activity which accelerates the hydroxylation of vitamin D, as well as the catabolism of vitamin D from 25hydroxycholecalciferol and 1,25-dihydroxycholecalciferol into inactive products leading to a reduction in vitamin reserves and increasing daily needs ${ }^{9}$. It could be presumed that the patients in this study had an adequate synthesis of vitamin D as they came from a region situated between a latitude 20 to 24 degrees and were exposed to right sunlight throughout the year. This asumption was confirmed by the fact that they had the same levels of $25(\mathrm{OH})$ VITD as the control group. This indicated the possibility that the endogenous synthesis of vitamin $\mathrm{D}$ in young adults of this region met the hormonal needs that had been increased by the anticonvulsants. And finally, the predominant therapy schedule was monotherapy $(83 \%)$, which produces less alterations in bone mass, than polytherapy does ${ }^{3}$.

The mean serum levels of calcium, found in the patients, were less than those in the control group. These results confirm those found in literature, showing the mean reduction in calcium serum levels as $0.3-0.8 \mathrm{mg} / \mathrm{dl}^{3}$. In the present study however, the reduction found was $0.3 \mathrm{mg} / \mathrm{dl}$, which is the lower limit of this variation and was not enough to increase the PTH serum levels and was not associated with the metabolism of vitamin $\mathrm{D}$. This reduction in the calcium serum levels could be attributed to the direct action of the anticonvulsants in the cells (intestine and bone) as shown in the case of phenobarbital and phenytoin but this has not yet been proven. However, in the case of carbamazepine, this asumption was in agreement with normal levels of serum 25-hydroxycholecalciferol that were found ${ }^{3,10,11}$.

The mean total alkaline phosphatase serum levels were significantly higher in the patients than in the control group. Richens \& Rowe ${ }^{5}$ measured the serum levels of alkaline phosphatase isoenzymes in chronic anticonvulsant users and found that the hepatic fraction was predominant $(60 \%)$. This result was similar to the one obtained by Hahn et al. ${ }^{6}$, which showed an increase in the hepatic isoenzyme in recent anticonvulsant users (up to six months). This increase in hepatic alkaline phosphatase serum, which may alter hepatic function, could be due to the chronic use of anticonvulsant medication ${ }^{12}$. Besides finding an increase in alkaline phosphatase, Weinstein et al. ${ }^{13}$ found increased serum levels of gamma-glutamil-transferase in $88 \%$ of chronic anticonvulsant users. Therefore, the increased alkaline phosphatase levels found in this present study were probably due mainly to hepatic isoenzyme. This hypothesis is strengthened by the fact that vitamin D serum levels found in patients were similar to those of the control group. 


\section{Conclusions}

The results of this study conclude that in a sample of Brazilian epileptic adult outpatients living in a region situated below 24 degrees latitude, with very intense sunlight exposure throughout the year, chronic anticonvulsant treatment was not associated to alterations of bone mineral density and vitamin D metabolism. However, other studies, carried out in a low latitude region, with epileptic patients on chronic anticonvulsant therapy presenting therefore great risk for bone disease, are necessary to show all the impact of anticonvulsant medication on the metabolism of calcium and bone mineral density.

Acknowledgments - The authors would like to thank Mrs. Cleide Moreira Silva and Mrs. Andréa Ferreira (members of the Research Commission of The Faculty of Medical Sciences) for providing statistical analysis and FAEP (Fundo de apoio ao ensino e a pesquisa)- FCM-UNICAMP for financial support.

\section{REFERENCES}

1. Dent CE, Richens FRS, Rowe DJF, Stamp TCB. Osteomalacia with long term anticonvulsant therapy in epilepsy. Br Med J 1970;4:69-72.

2. O‘Hare JA, Duggan B, O`Driscoll D, Callaghan N. Biochemical evidence for osteomalacia with carbamazepine therapy. Acta Neurol Scand 1980;62:282-286.

3. Hanh TJ. Steroid and drug-induced osteopenia. In Favus MJ, et al (eds). Primer on the metabolic bone diseases and disorders of mineral metabolism. New York: Raven Press, 1993:250-255.

4. Gough H, Goggin T, Bissessar A, Baker M, Crowley M, Callaghan N. A comparative study of the relative influence of different anticonvulsant drugs, UV exposure and diet on vitamin D and calcium metabolism in out-patients with epilepsy. Q J Med 1986;230:569-577.

5. Richens A, Rowe DJF. Disturbance of calcium metabolism by anticonvulsant drugs. Br Med J 1970;4:73-76

6. Hahn TJ, Hendin BA, Scharp CR, Haddad JG Jr. Effect of chronic anticonvulsant therapy on serum 25-hydroxycalciferol level in adults. N Engl J Med 1972;287: 900-904.

7. Parfitt AM, Gallagher JC, Heaney RP, Johnston CC, Neer R, Whedon GD. Vitamin D and bone health in the elderly. Am J Clin Nutr 1982;36:1014-1031.

8. Webb AR, Kline L, Holick MF. Influence of season and latitude on the cutaneous synthesis of vitamin D3: exposure to winter sunlight in Boston and Edmonton will not promote vitamin D synthesis in human skin. J Clin Endocrinol Metab 1988;67:373-378.

9. Kruse K. On the pathogenesis of anticonvulsant-drug-induced alterations of calcium metabolism. Eur J Pediatr 1982;138: 202-205.

10. Koch HU, Kraft D, Herrath DV, Schaefer K. Influence of diphenylhydantoin and phenobarbital on intestinal calcium transport in the rat. Epilepsia 1972;13:829-834.

11. Hahn TJ, Scharp CR, Richardson CA, Halstead LR, Kahn AJ, Teitelbaum SL. Interaction of diphenylhydantoin(phenytoin) and phenobarbital with hormonal mediation of fetal rat bone resorption in vitro. J Clin Invest 1978;62:406-414.

12. Frame B. Hypocalcemia and osteomalacia associated with anticonvulsant therapy. Ann Inten Med 1971;74:294-295.

13. Weinstein RS, Bryce GF, Sappington LJ, King DW, Gallagher BB. Decreased serum ionized calcium and normal vitamin D metabolite levels with anticonvulsant drug treatment. J Clin Endocrinol Metab 1984;58:1003-1009. 